\title{
The Power of the Family:
}

\section{Kinship and Intra-household Decision Making in Rural Burundi.*}

March 31, 2016

\begin{abstract}
:
In this paper we show that in rural Burundi the characteristics of the female's kinship are highly correlated with female's bargaining power, as proxied by her decision-making power. First, a female whose own immediate family is at least as rich as her husband's counterpart enjoys a greater say over children- and asset-related decision-making. Second, the size, relative wealth and proximity of the extended family also matter. Third, kinship characteristics prove to be more important than (standard) individual and household characteristics. Finally, we also show that the female's say over asset-related decisionmaking is positively associated with males' education, more than with female's education per se. All these correlation patterns can inform policies aiming at empowering women or targeting children through women's empowerment.
\end{abstract}

Keywords: Female decision-making, children, assets, kinship, rural Burundi.

JEL codes: D19, D63, J12, J13, J16.

* The authors would like to thank the Editor Shoshana Grossbard and the two anonymous referees for their insightful and constructive comments. They also thank the participants of the 2014 ENTER JAMBOREE in Stockholm-Sweden and of the International Economic Association World Congress in AmmanJordan for useful discussion. The authors gratefully acknowledge financial support of the FNRS/FRFC (Fonds National de la Recherche Scientifique/Fonds de la Recherche Fondamentale Collective). 


\section{INTRODUCTION.}

Gender equality and women's empowerment are called for by the 2000 United Nations Millenium Declaration as the third Millenium Development Goal (MDG3). (Women's) empowerment is a broad, multidimensional and context-specific concept that is not easy to define. One general definition common in the literature states that: "Empowerment is the expansion in people's ability to make strategic life choices, (particularly) in contexts where this ability had been denied to them" (Kabeer, 1999, p. 437). Women's empowerment is not (only) argued for as an end in itself. There is a persuasive claim that women's empowerment yields good policy pay-offs in terms of well-being of women themselves, fertility behavior and demographic transition, children's welfare and infant mortality, economic growth and poverty alleviation.

The concepts of gender inequality and empowerment are closely linked to the intrahousehold power distribution. That is, the underlying theoretical model motivating this statement is a collective bargaining model (Chiappori, 1988, 1992), which assumes that each individual has his or her own individual preferences and that the household decisions are therefore the outcome of a bargaining process. ${ }^{1}$ The bargaining power of household members is then summarized in a Pareto weight, which is itself a function of the so-called distribution factors (Bourguignon et al., 2009). ${ }^{2}$

Our paper contributes to the empirical literature on women's bargaining power. As we discuss in detail in the next section, this literature has mainly focused on the impact of economic (labor market participation, labor income, non-labor income, access to financial services, etc.) and human capital (education, health, etc.) proxies. However, following (Attanasio and Lechene, 2014), we will focus on the impact of kinship. Social norms and social aspects of bargaining power are reliable and strong determinants of intra-household bargaining power, especially for women (Agarwal, 1997). As a social resource, "kinship and family network is relevant for household behavior..." (Angelucci et al., 2010, p. 197) and "often fulfills roles that economists normally attribute to other entities..." (Cox and Fafchamps, 2008, p.3718).

\footnotetext{
${ }^{1}$ See e.g. Vermeulen (2005) for a thorough review of non-unitary models of household behavior.

${ }^{2}$ Exogenous variables that affect household decisions but not the preferences nor the budget constraint.
} 
In this study, we focus on Burundian households. Most of the studies on bargaining power have been carried out in Asia and Latin America. As discussed in detail in Malhotra et al. (2002) and the recent review by Doss (2013), this may lead to regional bias in the conclusions. That is, the relevant determinants of women's bargaining power, say, in Asia may turn out to be less, or even not at all, relevant in the African context given the importance of socio-cultural norms in setting intra-household power relations (Agarwal, 1997) and the differences across the two regions (Goody, 1976; Lesthaeghe, 1989; Caldwell and Caldwell, 1987, 1988, 1990). More generally, there is a need for understanding relevant factors for a specific context.

This paper tries to fill in this gap in the literature. Our main research question is to investigate the relationship between women's kin network and women's bargaining power, as proxied by her final say in the intra-household decision-making process, in rural Burundi. The main findings of our study are the following. First, we find that a female whose own immediate family is at least as rich as her husband's immediate family enjoys a greater say over children- and asset-related decision-making. Second, a female with a larger and wealthier extended household also enjoys such a greater say, particularly over asset-related decision-making. Female's extended relatives living outside the female's village seem to matter more than those living within her village for female's say over children-related decision-making. Third, kinship characteristics prove to matter for female's say more than standard individual and household characteristics. Fourth, for asset-related decision-making, male's education, rather than female's education per se, turns out to be positively and significantly associated with female's say.

The remainder of the paper is presented as follows. Section 2 reviews the empirical literature related to this paper. Section 3 presents and describes the data. Section 4 describes the methodology and Section 5 presents the econometric results. Finally, Section 6 concludes the paper.

\section{RELATED LITERATURE.}

This paper is related to two different strands of empirical literature. First, the literature on the determinants of women's bargaining power. Economic and human capital factors 
have been the most widely investigated determinants of intra-household bargaining power (see e.g. Grossbard-Shechtman (1993) for a comprehensive review). Examples of such factors are (i) assets and landownership (Grossbard-Shechtman, 1982; Allendorf, 2007), (ii) (gap in) employment status, wage/income and lifetime earnings (Sathar and Kazi, 1997; Elder and Rudolph, 2003; Woolley, 2003; Friedberg and Webb, 2006; Bertocchi et al., 2014), (iii) financial knowledge and the recipient of microcredit (Elder and Rudolph, 2003; Binaté Fofana et al., 2015), (iv) education and female-male education gap (Elder and Rudolph, 2003; Lührmann and Maurer, 2008; Bertocchi et al., 2014). Next, it has also been documented that household demographics and the socio-cultural context matters. Examples of such factors are (i) age (Grossbard, 1976; Sathar and Kazi, 1997; Balk, 1997; Bertocchi et al., 2014), (ii) size of the family (Bertocchi et al., 2014), (iii) health status (Lührmann and Maurer, 2008), (iv) race and religion (Friedberg and Webb, 2006). To acknowledge these previous findings, we included in our empirical analysis several covariates that are directly related to the ones mentioned above.

Our paper is also related to the empirical literature on kinship, which shows that kinship plays a role in various domains. Jacoby and Mansuri (2010) show that, in Rural Pakistan, the presence of a woman's brother protects her from intra-household conjugal violence through watta-satta marriage contracts ${ }^{3}$. Alesina and Giuliano (2010), using an index of strength of family ties, find that strong family ties are associated with higher home production (defined as child caring, home cooking, caring for the elderly, house keeping, etc...), bigger family, lower labor force participation of women and youngsters and lower geographic mobility. Kohler and Hammel (2001) aggregate, for each household, the distance-weighted resources of labor, oxen and cultivated land that were found in all other households with the same last name into network variables for labor, oxen and cultivated land. The authors thus prove that kinship networks increase the efficiency of agricultural production. In the context of PROGRESA, Angelucci et al. (2010) demonstrate that kinship, as identified through surnames, also matters for the effectiveness of social policies and programs. In particular they focus on the effect of cash transfers (and more generally

\footnotetext{
${ }^{3}$ Watta-satta is a kind of bride exchange custom that usually involves the simultaneous marriage of a brother-sister pair from two households. When a husband mistreats his wife in this arrangement, he can expect his brother-in-law to retaliate in kind against his sister.
} 
treatment effects) on school enrollment. It is also well-known that kinship networks affect child survival rates, see Sear and Mace (2008) for an extensive review, and, more generally, female fertility rates (Nath et al., 2000; Sear et al., 2003; Tymicki, 2004; Newson et al., 2005).

We contribute to both strands of the literature by investigating the impact of the kinship network, and more in particular its wealth, size and proximity, on the female bargaining power. As we explain in more detail below, the latter will be proxied by the female say on respectively children and asset related decisions. While doing that we will control for the covariates mentioned above.

\section{DATA.}

\subsection{The data set: the 2012 Burundi household survey.}

In 2012, a research team from the Université Libre de Bruxelles (ULB) conducted a household survey in Burundi. As a third wave following the 2007 and 1998 surveys, the 2012 household survey aimed at tracking and reinterviewing the 1,408 households interviewed in the 2007 household survey. ${ }^{4}$ To keep a longitudinal approach possible, the 2012 questionnaire is similar to the 2007 questionnaire. However, the 2012 questionnaire consists of three sub-questionnaires, namely the common part and individual sub-questionnaires for the husband and wife. Moreover, it innovates by adding additional modules and questions to capture the intra-household and gender differences across several dimensions of interest in family economics such as individual time use, contribution to farm production, assets ownership and inheritance, decision-making power and hidden income and transfers. The 2012 survey was CAPI-based and spanned from September to December 2012. A pilot survey was conducted in a region not covered by our sample. There were five teams of five interviewers each. Throughout the fieldwork, each team received regular visits by one coordinator and three researchers from ULB to ensure survey and data quality.

The fieldwork was split into two phases. In the first one, interviewers tracked the 1,408 households in their 2007 locations. Households members who were found were interviewed:

\footnotetext{
${ }^{4}$ For further details on the first and second wave, we refer to the 2012 survey report available at http://www.microconflict.eu/news/isteebu_report_en.pdf
} 
the women answered the common and female sub-questionnaires, while men answered the male sub-questionnaire. Interviewers also collected information on the whereabouts of those households members who were not found. In the second phase of the survey, the latter were then tracked and interviewed, including those households or individuals who had moved to Bujumbura, the capital. Overall, out of the 1,408 households surveyed in $2007,1,263$ were found and re-interviewed in 2012 , i.e a resurvey rate of $89.7 \%$. This is a novel and original data set that is used for the first time.

For the purpose of our paper, we only use the households in the 2012 wave, where both the husband and the wife have been interviewed. Single households, households where one of the spouses was absent or where the two respondents were blood-related (e.g. brother and sister, mother and son) were excluded from our analysis. This left us with a data set of 643 households.

\subsection{Women's empowerment variables.}

Women's empowerment is proxied by women's decision-making power within the household. Our survey questionnaire asked "who has the final say when it comes to making a given decision". The original dataset contains both males' and females' answers about their respective final say over 11 decision items. For this paper, we make use of six decision items of which three are children-related (i.e. "Who decide(s) when it comes to taking a sick child at the hospital", "Who decide(s) when it comes to sending a child to school" and "Who decide(s) about children clothing expenses") and the other three are asset-related (i.e. "Who decide(s) when it comes to making large investments", "Who decide(s) when it comes to selling assets" and "Who decide(s) when it comes to purchasing durable goods"). ${ }^{5}$

Our motivation for focusing on these two categories is twofold. First, and most importantly, children-related decision-making is one of the double dividend of advocating women's empowerment (UNICEF, 2006). Understanding the mechanics about what drives female say may therefore be directly policy relevant. However, and this is our motivation to use our three asset-related questions, there may be a bias due to cultural norms. For

\footnotetext{
${ }^{5}$ The 5 other decision-making items are: "Who decide(s) over how to spend the male's income?", "Who decide(s) over how to spend the female's income?", "Who decide(s) over food expenditures", "Who decide(s) over transfers to male's parents?", "Who decide(s) over transfers to female's parents?"
} 
instance, in Burundi children's care is commonly considered to be a female-specific task, while asset holding is mainly a male's privilege. Thus, a female's greater say in childrenrelated decision-making might just be the result of such gender division of tasks and responsibilities, rather than a real bargaining process. Moreover, such a female greater say may also result from gender discrimination (Doepke and Tertilt, 2011). Therefore, we use asset-related decision-making as a kind of robustness check to investigate the impact of kinship on female bargaining power. That is, we check if our kinship variables have a similar impact on our proxy for bargaining power based on, respectively, the children-related and the asset-related questions.

The empowerment questions were asked to both spouses and, therefore, we have both male and female opinions. In this paper we only focus on these households for which both partners gave a coherent answer (henceforth indicated by JOPIN-based female say). This choice obviously leads to more accurate and internally consistent results. We refer to the working paper version of this paper (Ngenzebuke et al., 2014) for some empirical results on the internal consistency and inter-spouse agreement.

Table 4 in the Appendix presents some descriptive statistics on the JOPIN-based answers to a given decision-making question. It turns out that joint decision-making occurs in most of the six dimensions, whereas, overall, the proportion of male sole decisionmakers exceeds by far the proportion of female sole decision-makers, particularly for assetrelated decision-making. For the econometric analysis, we construct, for each decisionmaking item, one dummy variable taking on value 1 if the wife has at least some say (either the female solely decides or both spouses jointly decide) and 0 elsewhere (when the male solely decides).

\subsection{Kinship variables.}

Some papers in the kinship literature use an identification strategy based on surnames (Kohler and Hammel, 2001; Angelucci et al., 2010). This is however not possible in our Burundian context since there is no standard naming convention. Not only is there no matronymic naming practice, but also the patronymic naming practice (promoted by the colonization and christianity), actually coexists with the traditional naming system 
wherein a father and his children bear different surnames (see Simbananiye, 2005, for further information on the naming practices in Burundi). Therefore, in our survey male and female respondents were asked some questions about their respective immediate and extended family.

\subsubsection{Immediate family.}

Each spouse was asked to indicate which of the male and female respective immediate families (i.e. parents, sisters and brothers) was the relatively richer one. The possible answers were "male immediate family", "female immediate family" or "no significant difference". As before, in our econometric models we only retained those households for which both spouses gave a coherent answer. This is even more important for these questions given the relative interpretation our respondents could give to the term "richer".

In $57.78 \%$ of households, there is no significant difference in the wealth of male's and female's respective immediate families. The male's respective immediate family is relatively richer in $24.60 \%$ of households, while in the remaining $17.62 \%$ of households, the female's respective immediate family is the relatively richer. In the regression analysis, we use a dummy variable that takes on value 1 if the female's immediate family is at least as rich as the male's immediate family and 0 otherwise.

\subsubsection{Extended family.}

Each spouse was asked to report the number of his/her own extended family members living within the same village and with whom (s)he has a close relationship. Moreover, the respondents had to specify how many of those relatives are richer, as rich as or poorer than his/her own household. The same questions were reiterated for those relatives living outside the respondent's village. See Table 5 in the Appendix for the exact list of survey questions.

Table 6 in the Appendix presents some summary statistics for our extended family variables. When focusing on the total sum of the extended family (i.e. both inside and outside the village), the headcount of male's extended relatives is, on average, (significantly) larger than that of female's extended relatives, regardless of their wealth status. 
Further, from columns 5 and 6 , it appears that the percentage of households wherein the headcount of male's relatives (again regardless of their wealth status) is strictly larger (as compared to the headcount of female's counterpart) exceeds the percentage of households wherein the opposite relationship holds. Next, the shares of male's and female's richer (poorer, respectively) relatives, are not statistically different and cluster around $40 \%$ (25\%, respectively). Moreover, from columns 5 and 6 , there is not much difference (at most 3.2 percentage points) between (i) the percentage of households wherein the share of male's richer (poorer, respectively) relatives is strictly larger than the share of female's richer (poorer, respectively) relatives versus (ii) the percentage of households wherein the share of male's richer (poorer, respectively) relatives is strictly smaller than the share of female's richer (poorer, respectively) relatives. As is clear from Table 6, qualitatively similar results hold with respect to the extended family inside (respectively outside) the village. Particularly, and this is in line with the patrilocal feature of marriage in Burundi, there are more male's kins within the village than outside the village, whereas female's kins are relatively numerous outside the village than within the village. There are more male's and female's richer kins (both in headcount and share) outside than within the village ${ }^{6}$.

\subsubsection{Measurement issues.}

Some measurement issues emerge at this point. First, in the context of Burundi, the scope of extended family can cover a lot of family ties that might rather be neglected in some other societies. The scope can also vary from one respondent to another. Thus, when asked to report the headcount of family members, the scope of extended family can entail some measurement issues. To the extent that the (extended) family matters, interaction is a prerequisite and measurement issues in reporting the headcount of family members tend to reduce when there is a strong interaction with them. Such measurement errors can also vary with the geographic proximity, as one can expect them to be less relevant for family members living close by. So as to minimize such type of measurement errors, respondents were asked to report extended family members (1) with whom they have a

\footnotetext{
${ }^{6}$ Although not reported in the Table 6 , t-test results show that these differentials are all statistically significant.
} 
close relationship and (2) who reside within and outside the village separately.

Second, we cannot rule out the plausible overlapping of extended family members. Indeed, both husband and wife may have some extended family members in common. According to whether the respondent does or does not report these relatives, this can raise a measurement error in the self-reported size of each spouse's extended family. However, there is no reason to think that one spouse underestimates the size of the extended family (by not accounting for common relatives) while the other does not in a systematic manner.

The third measurement issue has to do with the subjective cross-family comparison of "richness". One can question the ability of a respondent to accurately rate the wealth of an outsider family/household. We argue that the relevance of this concern may be put, to some extent, into perspective in the context of the rural areas that we are studying. In urban cities, people often originate from other locations (immigration) and generally have less interaction (individualism phenomenon) than in rural areas. Next, richness can be accumulated in diverse ways of which some are very ostentatious (e.g. cars, houses) but some are less ostentatious (e.g. money on bank accounts, some types of assets). However, in rural areas, there are many native people, who know each other and who interact more often than in urban cities. Also, in the case of rural Burundi, which is predominantly agricultural with some livestock, the assets are mainly land and livestock which feature a good visibility. All this makes us believe that our definition of "rich" is not that worrisome after all.

\subsection{Other covariates.}

The data at hand also provide information on individuals' and households' characteristics such as each spouse's age, education achievement, employment status, household expenditures, household size and marriage duration. Table 7 in the Appendix presents some descriptive statistics of the aforementioned covariates. As compared to females, males are older, better educated and more likely to be cash-potential workers. We deem an individual as a cash-potential worker if he/she is either an on-farm cash-crop farmer or an off-farm worker. The average household exists for 18 years, comprises (almost) 6 members and spends 11188 BIF (more or less 7 USD) per month. Half of the household members 
are children under fifteen and the children median age is 8 years.

\section{METHODOLOGY.}

Our empirical results are obtained on the basis of a trivariate probit model in which we estimate the likelihood that a female has at least some say as a function of the kinship variables and other covariates discussed in the previous section. We opted for a trivariate model, since, in contrast to a (univariate) probit model, such an analysis suitably accounts for possible correlation of the female say across different decision-making items. Within each category, there is expected to be a trivariate relationship between decision-making items. For instance, it is more likely that a female who decides when it comes to sending a child to school, is also more likely to be the decision-maker when it comes to taking a sick child to the hospital. Likewise, a female with little say when it comes to purchasing durables is less likely to have a greater say when it comes to reselling them.

Next, the trivariate probit model (with only two categories, no say versus some say) is, according to us, preferred over a trivariate ordered probit model, wherein the female say would be modeled as an ordinal variable with three categories (no say, joint say, sole say). In the Burundian society, even though a female could be as powerful as she wishes, it's less likely that she will prefer to be the sole decision-maker. Indeed, the Burundian society recognizes the man as having a great leadership role in the family, so that a wife who decides everything alone will not be respected. Moreover, as a matter of principle, women's empowerment and gender equality call for more gender equity and not for dictator-like power for women. All this is confirmed by our data since the number of cases where the female is the sole decision-maker is rather low and does therefore not justify using a trivariate ordered probit model. ${ }^{7}$

One could of course argue that the logic for the trivariate analysis also applies to a 6-equation multivariate analysis. However, the hypothesized tetrachoric correlation is likely to be stronger between decision-making items of the same category. That is, the intra-category tetrachoric correlation is expected to be higher than the inter-category

\footnotetext{
${ }^{7}$ Except over the first decision-making item ("when it comes to taking a sick child to the hospital"), the incidence of "female sole decision-maker" ranges between $0.62 \%$ and $6.24 \%$. Over the asset-related decision-making items, that frequency is $0.82 \%$ at most (see Table 4 in the Appendix).
} 
tetrachoric correlation. Next, since we focus on households in which both spouses answer the empowerment questions coherently, the 6-equation multivariate probit analysis would require to work with only 220 households since then we would need coherence for the 6 questions simultaneously. All this, coupled with the intrinsic complexity of the 6equation multivariate probit analysis, makes it practically impossible to do the Cholesky factorization of the rho matrix.

Four model's specifications are estimated. All the four models include, as main covariates, (i) a dummy that equals 1 if the female's respective immediate family is at least as rich as the male's counterpart and (ii) the absolute size of the female's extended family. On top of that, the second and third models additionally include the share of female's richer relatives and the share of female's relatives living outside the village, respectively, while the last model includes all the four kinship covariates. As explained above, we control for other (standard) individual and household characteristics. The former include the males' and females' age, education grade and job category, while the latter include the marriage duration, household size, child dependency ratio, children median age and household welfare as proxied by household monthly expenditures.

As a finale note, we want to stress that the relationship between the kinship variables and female decision-making say has to be interpreted with caution. One can rightfully argue that our estimation is subject to an endogeneity issue as there may exist unobserved variables that explain both the characteristics of the female's kinship and the female's decision-making power. In the lack of exogenous variation in kinship characteristics, it is recommended to interpret the results as mere correlations rather than causal effects. However, we believe that these correlation patterns are already interesting on their own right, particularly in the perspective of policy implications of our study, which we discuss Section 6 .

\section{ECONOMETRIC RESULTS.}

The trivariate probit estimates of female say over children- and asset-related decisionmaking are presented in Table 1 and Table 2, respectively. With respect to the childrenrelated decision-making, the trivariate probit results from Table 1 show that the relative 
wealth of the female's immediate family consistently matters for the female's decisionmaking power, regardless of the type of the decision. Also, the larger the female's extended family (both size and wealth), the greater the female's say.

Next, our estimates tend to suggest a relatively greater importance of outside-village relatives. Indeed, whenever the share of female's outside-village relatives is controlled for, it proves to be positively and significantly associated with the female's say over two children-related decision-making items. This is in line with the previous descriptive evidence that the share of female's richer relatives is statistically larger outside the (rural) village than within it. As a matter of fact, for men we observe the same evidence (i.e. share of richer relatives larger outside than within the village). These patterns could potentially be explained by the fact the these relative live in urban cities, or even abroad, which makes them on average wealthier. Unfortunately our data does not allow to further investigate this hypothesis.

As for the other covariates, female's age is negatively and significantly (but not linearly) associated with the female's decision-making power over children-related decisionmaking items. Next, as compared to a female with no education, female with primary education or more than primary education, enjoys more say over children-related decisionmaking item(s). Finally, our results suggest that the other covariates, including child characteristics, are (mostly) not statistically correlated with female say.

With respect to our robustness exercise on asset-related decision making, we show in Table 2 that we obtain qualitatively similar results. Importantly, our conclusions for the impact of the kinship network are still the same. However, the impact of the other covariates is slightly different. In particular, women from households in higher tertiles of the welfare distribution are more likely to have some say over asset-related decisionmaking than women from households in the lowest tertile. Next, while male's education turns out to not (statistically) matter for children-related decision-making, it is quite the opposite for asset-related decision-making. Indeed, as compared to "zero education", "more than primary education" for male is positively and significantly associated with the likelihood that the female decides over all the three asset-related decision-making items. This twofold finding is worth stressing. It is arguable that male's education can shape 
their attitude towards more female-empowerment fairness which, in turn, translates into more female say over a such male-ascribed decision-making domain, namely asset-related decision-making in the local context of rural Burundi, regardless of the female's education.

As a final empirical exercise, we want to focus on the importance of our covariates. Our full set of covariates fall in three broad categories, namely (female) kinship characteristics, (spousal) individual characteristics and household characteristics. It is therefore interesting to assess how much more important one category of covariates is relatively to the other(s). For this purpose, we resort to the Akaike Information criterion (AIC), which underlies the relative likelihood test, so as to assess the relative quality of models excluding at least one of the three sets of covariates. The lower the information criterion, the (relatively) better the model.

Panel A and B of Table 3 display the ranking of children-related decision-making models and asset-related decision-making models, respectively, according to the corresponding information criteria. Unquestionably, the full model is the best with the lowest AIC and BIC (Bayesian Information Criterion). But more interestingly, the model excluding kinship variables (but including the individual and household characteristics) ranks below both the model excluding individual characteristics and the model excluding household characteristics. Furthermore, the model including kinship variables solely ranks above both the model including individual characteristics only and the model including household characteristics only.

\section{DISCUSSION AND CONCLUSION.}

This paper documents the relationship between a woman's kinship network and her decision-making power over children- and asset-related items in rural Burundi. The central finding is that family networks characteristics matter for female's intra-household decision-making, even more than (standard) individual and household characteristics. More precisely, women whose family (either immediate or extended) is richer than her husband's have a greater say in intra-household decision-making. In an attempt to bring out the role played by the proximity of the family, we found that the share of female's extended family living outside the village is positively associated with the female's decision-making 
power. We argue that this finding is likely driven by relatives living in outside-village wealthier locations, such as urban cities or abroad. Nevertheless, the way we measured proximity of the extended family (i.e. within versus outside the village) provides only a narrow proxy and we acknowledge that better proxies, which further disentangle the type of outside-village location, could shed more light on the role of proximity.

As indicated above, we refrain from interpreting our results as a causal relationship. However, to the extent that one could think of a causal effect of family network on intrahousehold bargaining power, the former could matter for the latter through the following channels. First, women from larger and richer families are more likely to bring assets to the marriage than women from smaller and poorer families and are, thus, more likely to enjoy a better bargaining position within the marriage. Second, women from larger and richer families can expect more monetary and non-monetary transfers, as well as any kind of emotional or social support from their relatives during quiet times and, most notably, in times of trouble such as unexpected household shocks. This interpretation is in line with a couple of studies highlighting that inter-household transfers are risk-sharing mechanisms (Fafchamps and Gubert, 2007b,a). Third, a larger and richer original family assures a better outside option to the woman if her marriage were to dissolve. Such women, therefore, enjoy a better position in the intra-household bargaining and decisionmaking processes. Proper investigation of these hypothesized channels is part of our future research agenda.

Finally, our correlation patterns suggest the following policy recommendations. First, policies that aim at empowering women should more carefully target females originally from poorer families. Not only might such women be more likely to be poor themselves due to inter-generational transmission of poverty, but they are also less likely to enjoy a better position in decision-making within their own household. Second, in line with the maternalist argument that women's empowerment is good for children's welfare, policies targeting children's well-being should also be designed in a way that accounts for the presence and characteristics of family networks. Third, policies aiming at (really) empowering women should also involve men, as our results showed that the male's education is positively associated with the female's say over asset-related decision-making, a male-ascribed 
domain in the context of (rural) Burundi. In some contexts, from their childhood, boys might be socialized into some gender roles promoting male supremacy. If so, education can shape and shift their tradition and culture-instilled behavior toward gender-equitable behavior. In a broader sense, education should be understood as embracing formal education as well as any training program that make men sensitive to more gender-equitable practices and behavior. 


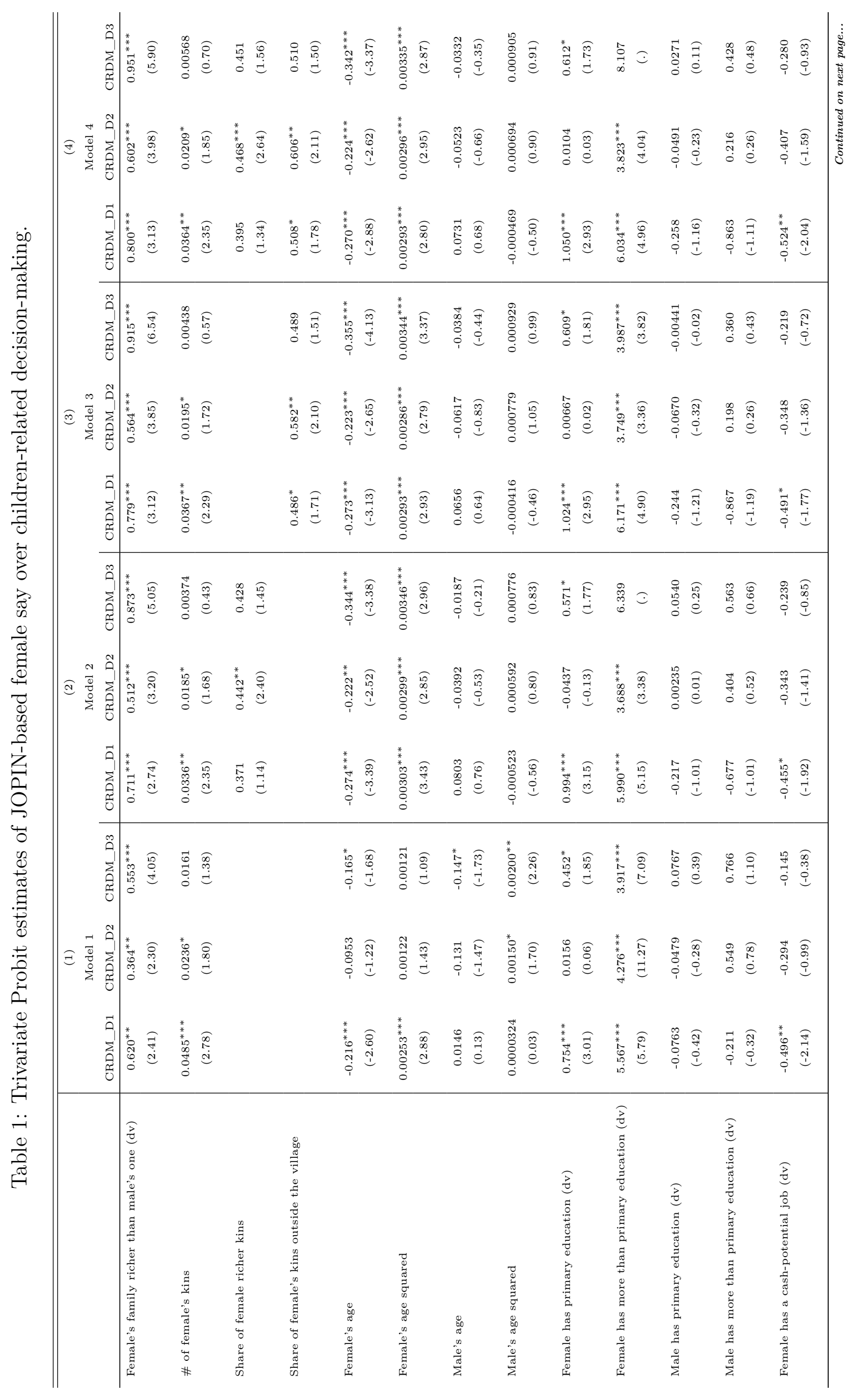




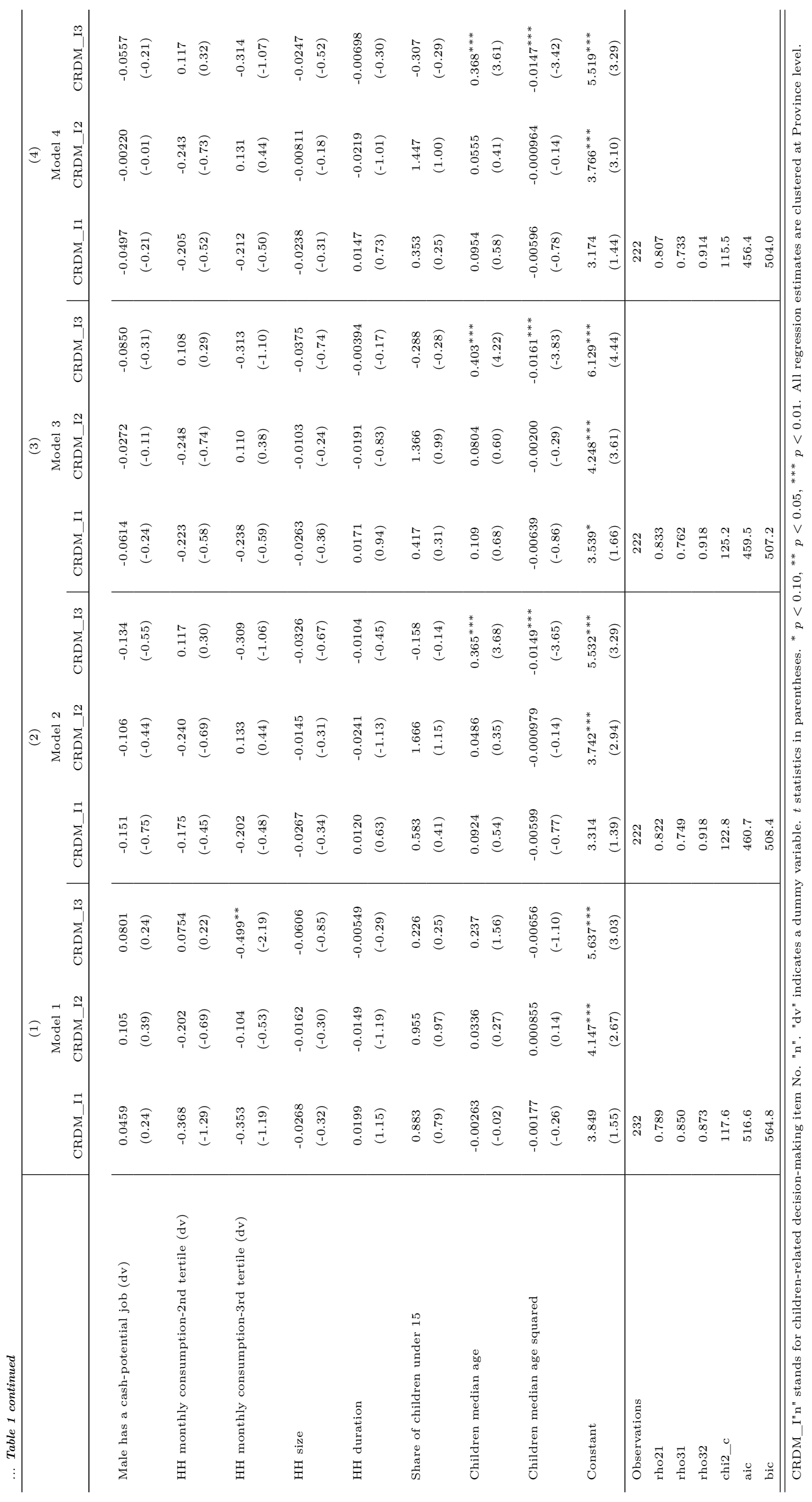




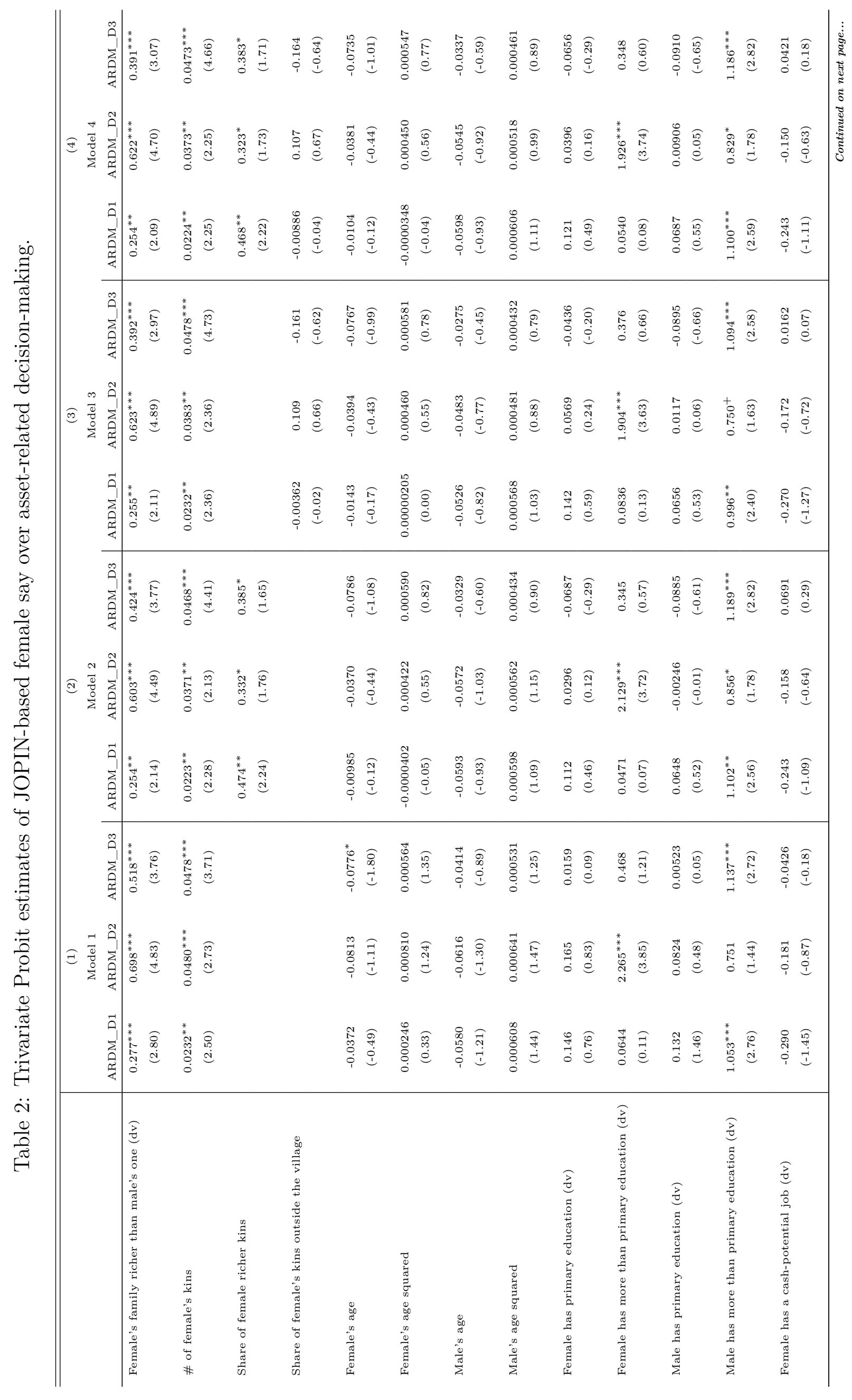




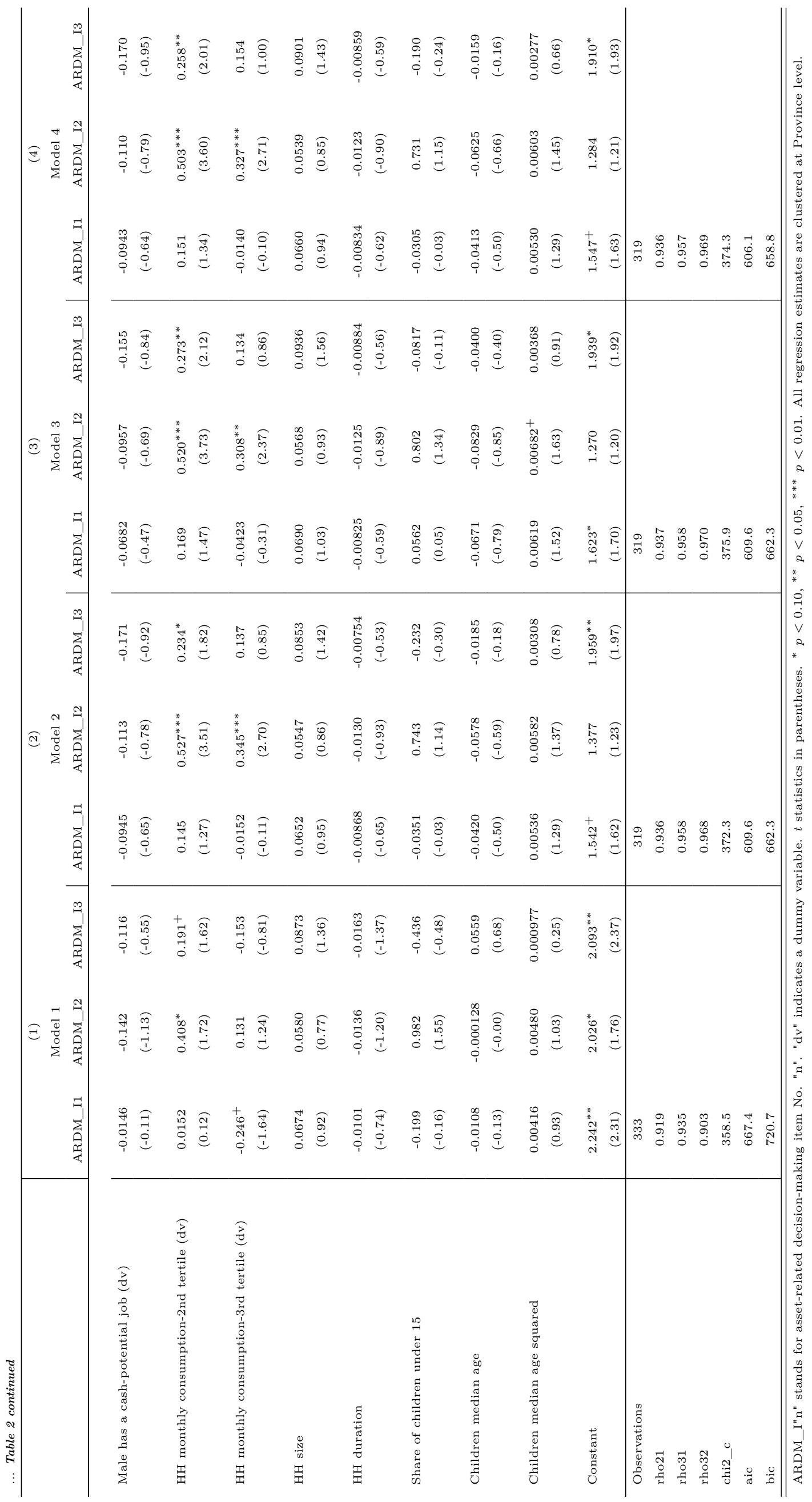



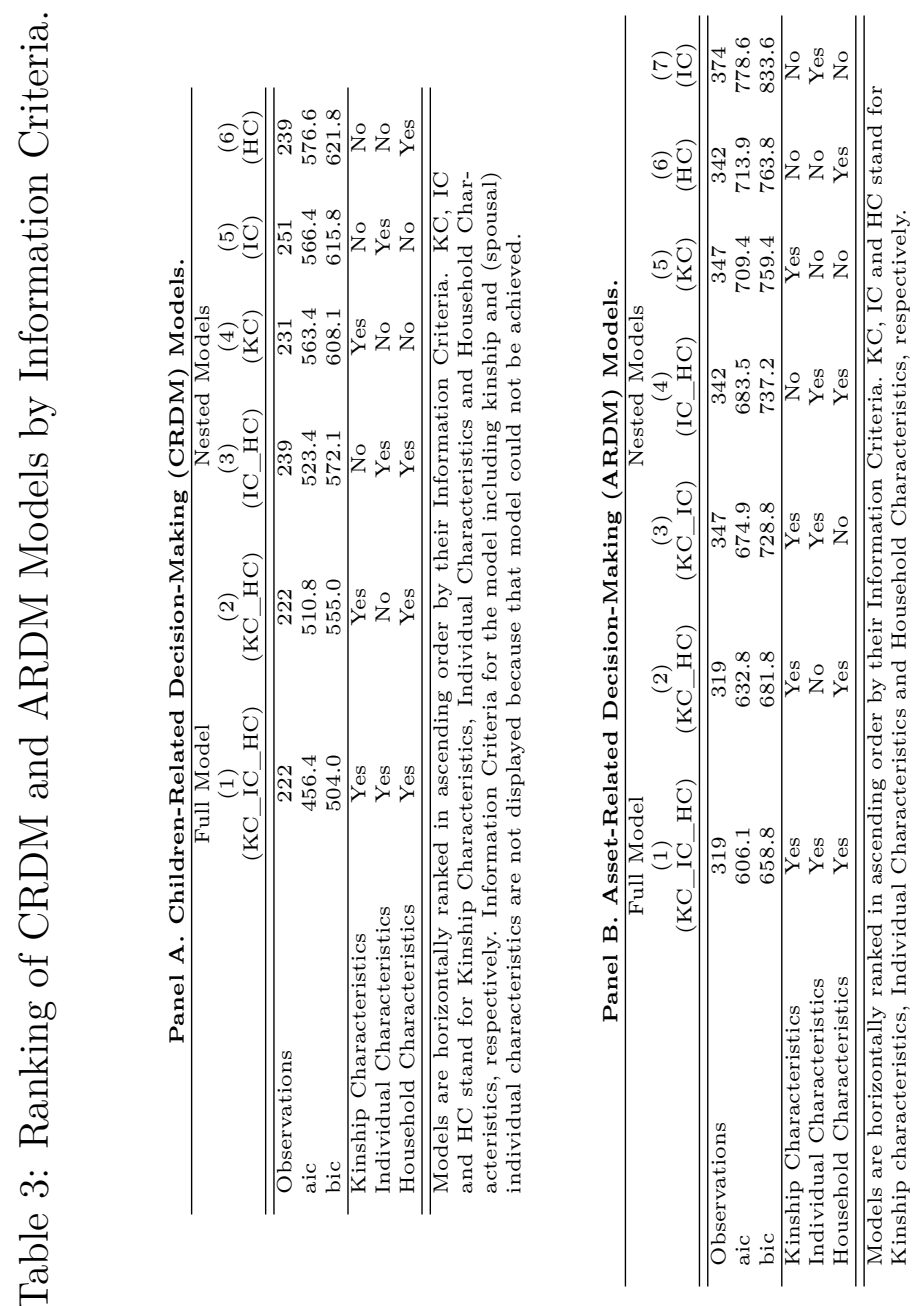


\section{Compliance with ethical standards.}

Funding and Conflict of interest: This study was funded by the Fonds National de la Recherche Scientifique. The authors declare that they have no conflict of interest.

\section{References}

Agarwal, B. (1997). "bargaining" and gender relations: Within and beyond the household. Feminist Economics, 3(1):1-51.

Alesina, A. and Giuliano, P. (2010). The power of the family. Journal of Economic Growth, 15(2):93-125.

Allendorf, K. (2007). Do women's land rights promote empowerment and child health in nepal? World Development, 35(11):1975-1988.

Angelucci, M., De Giorgi, G., Rangel, M. A., and Rasul, I. (2010). Family networks and school enrolment: Evidence from a randomized social experiment. Journal of Public Economics, 94(3-4):197-221.

Attanasio, O. P. and Lechene, V. (2014). Efficient responses to targeted cash transfers. Journal of Political Economy, 122(1):178-222.

Balk, D. (1997). Defying gender norms in rural bangladesh: A social demographic analysis. Population Studies, 51(2):pp. 153-172.

Bertocchi, G., Brunetti, M., and Torricelli, C. (2014). Who holds the purse strings within the household? The determinants of intra-family decision making. Journal of Economic Behavior \&6 Organization, 101(C):65-86.

Binaté Fofana, N., Antonides, G., Niehof, A., and Ophem, J. A. C. (2015). How microfinance empowers women in côte d'ivoire. Review of Economics of the Household, 13(4):1023-1041. 
Bourguignon, F., Browning, M., and Chiappori, P.-A. (2009). Efficient intra-household allocations and distribution factors: Implications and identification. Review of Economic Studies, 76(2):503-528.

Caldwell, J. C. and Caldwell, P. (1987). The cultural context of high fertility in subsaharan africa. Population and Development Review, 13(3):pp. 409-437.

Caldwell, J. C. and Caldwell, P. (1988). Is the Asian family planning program model suited to Africa? Studies in family planning, 19(1):19-28.

Caldwell, J. C. and Caldwell, P. (1990). Cultural Forces Tending to Sustain High Fertility. pages 199-214.

Chiappori, P.-A. (1988). Rational household labor supply. Econometrica, 56(1):63-90.

Chiappori, P.-A. (1992). Collective labor supply and welfare. Journal of Political Economy, 100(3):437-67.

Cox, D. and Fafchamps, M. (2008). Extended Family and Kinship Networks: Economic Insights and Evolutionary Directions, volume 4 of Handbook of Development Economics, chapter 58, pages 3711-3784. Elsevier.

Doepke, M. and Tertilt, M. (2011). Does female empowerment promote economic development? IZA Discussion Papers 5637, Institute for the Study of Labor (IZA).

Doss, C. (2013). Intrahousehold bargaining and resource allocation in developing countries. World Bank Research Observer, 28(1):52-78.

Elder, H. W. and Rudolph, P. M. (2003). Who makes the financial decisions in the households of older americans? Financial Services Review, 12:293 - 308.

Fafchamps, M. and Gubert, F. (2007a). The formation of risk sharing networks. Journal of Development Economics, 83(2):326 - 350 .

Fafchamps, M. and Gubert, F. (2007b). Risk sharing and network formation. American Economic Review, 97(2):75-79. 
Friedberg, L. and Webb, A. (2006). Determinants and consequences of bargaining power in households. NBER Working Papers 12367, National Bureau of Economic Research, Inc.

Goody, J. (1976). Production and Reproduction: A Comparative Study of the Domestic Domain. Cambridge Studies in Social and Cultural Anthropology. Cambridge University Press.

Grossbard, A. (1976). An economic analysis of polygyny: The case of maiduguri. Current Anthropology, 17(4):701-707.

Grossbard-Shechtman, S. (1993). On the Economics of Marriage: A Theory of Marriage, Labor, and Divorce. Westview Press.

Grossbard-Shechtman, S. A. (1982). A Theory of Marriage Formality: The Case of Guatemala. Economic Development and Cultural Change, 30(4):813-30.

Jacoby, H. G. and Mansuri, G. (2010). Watta satta: Bride exchange and women's welfare in rural pakistan. American Economic Review, 100(4):1804-25.

Kabeer, N. (1999). Resources, agency, achievements: Reflections on the measurement of women's empowerment. Development and Change, 30(3):435-464.

Kohler, H.-P. and Hammel, E. A. (2001). On the role of families and kinship networks in pre-industrial agricultural societies: An analysis of the 1698 slavonian census. Journal of Population Economics, 14(1):pp. 21-49.

Lesthaeghe, R. J. (1989). Reproduction and Social Organization in Sub-Saharan Africa. Piers Plowman-The Three Versions. University of California Press.

Lührmann, M. and Maurer, J. (2008). Who wears the trousers? a semiparametric analysis of decision power in couples. MEA discussion paper series 08168, Munich Center for the Economics of Aging (MEA) at the Max Planck Institute for Social Law and Social Policy. 
Malhotra, A., Schuler, S. R., and Boender, C. (2002). Measuring Women's Empowerment as a Variable in International Development. In Workshop on Poverty and Gender: New Perspectives. World Bank.

Nath, D. C., Leonetti, D. L., and Steele, M. S. (2000). Analysis of birth intervals in a non-contracepting indian population: An evolutionary ecological approach. Journal of Biosocial Science, 32:343-354.

Newson, L., Postmes, T., Lea, S. E. G., and Webley, P. (2005). Why are modern families small? Toward an evolutionary and cultural explanation for the demographic transition. Personality and social psychology review : an official journal of the Society for Personality and Social Psychology, Inc, 9(4):360-375.

Ngenzebuke, R. L., De Rock, B., and Verwimp, P. (2014). The Power of the Family: Kinship and Intra-Houselhold Decision-Making in Rural Burundi. Working Papers ECARES 2014-29, ULB - Universite Libre de Bruxelles.

Sathar, Z. A. and Kazi, S. (1997). Women's autonomy, livelihood ES fertility : a study of rural Punjab. Pakistan Institute of Development Economics, Islamabad, Pakistan.

Sear, R. and Mace, R. (2008). Who keeps children alive? a review of the effects of kin on child survival. Evolution and Human Behavior, 29(1):1 - 18.

Sear, R., Mace, R., and McGregor, I. A. (2003). The effects of kin on female fertility in rural gambia. Evolution and Human Behavior, 24(1):25-42.

Simbananiye, L. (2005). Les noms de personnes au burundi: Un support du lien social. Anthropologie et Sociétés, 29(1):167-181.

Tymicki, K. (2004). Kin influence on female reproductive behavior: The evidence from reconstitution of the bejsce parish registers, 18th to 20th centuries, poland. American Journal of Human Biology, 16(5):508-522.

UNICEF (2006). The State of the World's Children 200\%: Women and Children : the Double Dividend of Gender Equality. Sales number. United Nations Children's Fund. 
Vermeulen, F. (2005). And the winner is... An empirical evaluation of unitary and collective labour supply models. Empirical Economics, 30(3):711-734.

Woolley, F. (2003). Control over Money in Marriage. In marriage and the economy, S. Grossbard-Shechtman ed. N.Y: Cambridge U Press. 


\section{Appendix}

Table 4: Distribution of wife and husband's answers to decision-making questions with restrictions to agreement cases.

\begin{tabular}{|c|c|c|c|c|c|c|}
\hline \multirow[b]{2}{*}{ Question } & \multicolumn{6}{|c|}{ Answers } \\
\hline & & Male & Female & Both & Others & Total \\
\hline "Who decides when it comes to taking & $\#$ & 55 & 187 & 198 & 19 & 459 \\
\hline a sick child at the hospital" & $\%$ & 11.98 & 40.74 & 43.14 & 4.14 & 100 \\
\hline "Who decides when it comes to sending & $\#$ & 136 & 20 & 249 & 41 & 446 \\
\hline a child to school" & $\%$ & 30.49 & 4.48 & 55.83 & 9.19 & 100 \\
\hline "Who decides about children & $\#$ & 137 & 27 & 255 & 14 & 433 \\
\hline clothing expenses" & $\%$ & 31.64 & 6.24 & 58.89 & 3.23 & 100 \\
\hline "Who decides when it comes to & $\#$ & 128 & 3 & 351 & 2 & 484 \\
\hline making large investments" & $\%$ & 26.45 & 0.62 & 72.52 & 0.41 & 100 \\
\hline "Who decides when it comes to & $\#$ & 119 & 3 & 357 & 0 & 479 \\
\hline selling assets" & $\%$ & 24.84 & 0.63 & 74.53 & 0 & 100 \\
\hline "Who decides when it comes to & $\#$ & 154 & 4 & 329 & 0 & 487 \\
\hline purchasing durable goods & $\%$ & 31.62 & 0.82 & 67.56 & 0 & 100 \\
\hline
\end{tabular}


Table 5: List of kinship survey questions asked to both male and female.

Q1 Between your own immediate family (i.e. parents, sisters and brothers) and your partner's counterpart, which is the relatively richer?

Q2. How many extended relatives, living within your village and with whom you do interact, do you have?

Q2.a. How many of them do you deem as poorer than your own household?

Q2.b. How many of them do you deem as equally rich than your own household?

Q2.c. How many of them do you deem as richer than your own household?

Q3. How many extended relatives, living outside your village and with whom you do interact, do you have?

Q3.a. How many of them do you deem as poorer than your own household?

Q3.b. How many of them do you deem as equally rich than your own household?

Q3.c. How many of them do you deem as richer than your own household? 
Table 6: Summary statistics of the extended family variables.

Panel A.

\begin{tabular}{|c|c|c|c|c|c|c|}
\hline Variable & $\begin{array}{c}\text { Male kinship } \\
\text { Mean } \\
\text { (s.d) } \\
(1)\end{array}$ & $\begin{array}{c}\text { Female kinship } \\
\text { Mean } \\
(\text { s.d) } \\
(2) \\
\end{array}$ & $\begin{array}{c}\text { Mean difference } \\
\text { (3) }\end{array}$ & $\begin{array}{l}\text { T-test } \\
(4)\end{array}$ & $\begin{array}{c}\text { \% of HH where } \\
\text { MVV }>\text { FVV } \\
(5)\end{array}$ & $\begin{array}{c}\text { \% of HH where } \\
\text { MVV }<\text { FVV } \\
(6)\end{array}$ \\
\hline \multicolumn{7}{|l|}{ Regardless of the location } \\
\hline$\overline{\text { All kin_all }}$ & $\begin{array}{c}10.678 \\
(14.191)\end{array}$ & $\begin{array}{c}7.933 \\
(9.882)\end{array}$ & 2.745 & $4.025 * * *$ & 53.50 & 32.35 \\
\hline Richer kin_all & $\begin{array}{c}4.208 \\
(5.975)\end{array}$ & $\begin{array}{c}3.177 \\
(4.891)\end{array}$ & 1.031 & $3.386 * * *$ & 46.19 & 28.93 \\
\hline Equally-rich kin_all & $\begin{array}{c}3.765 \\
(7.120)\end{array}$ & $\begin{array}{c}2.802 \\
(4.186)\end{array}$ & 0.962 & 2.955 & 43.70 & 33.44 \\
\hline Poorer kin_all & $\begin{array}{c}2.705 \\
(4.473)\end{array}$ & $\begin{array}{c}1.972 \\
(3.143)\end{array}$ & 0.733 & $3.398^{* * *}$ & 39.19 & 25.35 \\
\hline Share of richer kin_all & $\begin{array}{c}0.406 \\
(0.323)\end{array}$ & $\begin{array}{c}0.404 \\
(0.343)\end{array}$ & 0.002 & 0.140 & 44.01 & 40.81 \\
\hline Share of poorer kin_all & $\begin{array}{c}0.251 \\
(0.260)\end{array}$ & $\begin{array}{c}0.247 \\
(0.259)\end{array}$ & 0.004 & 0.267 & 39.12 & 36.42 \\
\hline \multicolumn{7}{|l|}{ Inside the village } \\
\hline$\overline{\text { All kin_in }}$ & $\begin{array}{c}5.564 \\
(7.030)\end{array}$ & $\begin{array}{c}3.734 \\
(6.157)\end{array}$ & 1.830 & $4.966 * * *$ & 58.48 & 23.33 \\
\hline Richer kin_in & $\begin{array}{c}2.356 \\
(3.322)\end{array}$ & $\begin{array}{c}1.867 \\
(2.906)\end{array}$ & 0.488 & $2.501^{* *}$ & 40.64 & 26.48 \\
\hline Equally-rich kin_in & $\begin{array}{c}2.304 \\
(4.044)\end{array}$ & $\begin{array}{c}1.976 \\
(3.336)\end{array}$ & 0.327 & 1.409 & 38.58 & 29.22 \\
\hline Poorer kin_in & $\begin{array}{c}1.529 \\
(2.247)\end{array}$ & $\begin{array}{c}1.283 \\
(2.121)\end{array}$ & 0.245 & $1.804^{*}$ & 36.53 & 22.60 \\
\hline Share of richer kin_in & $\begin{array}{c}0.235 \\
(0.262)\end{array}$ & $\begin{array}{c}0.216 \\
(0.250)\end{array}$ & 0.019 & 1.176 & 42.47 & 34.47 \\
\hline Share of poorer kin_in & $\begin{array}{c}0.160 \\
(0.201)\end{array}$ & $\begin{array}{c}0.145 \\
(0.192)\end{array}$ & 0.015 & 1.206 & 38.13 & 30.59 \\
\hline \multicolumn{7}{|l|}{ Outside the village } \\
\hline$\overline{\text { All kin_out }}$ & $\begin{array}{c}5.113 \\
(8.474)\end{array}$ & $\begin{array}{c}4.199 \\
(4.996)\end{array}$ & 0.914 & $2.357^{* *}$ & 37.33 & 37.17 \\
\hline Richer kin_out & $\begin{array}{c}2.805 \\
(4.052)\end{array}$ & $\begin{array}{c}2.181 \\
(3.170)\end{array}$ & 0.624 & $2.747 * * *$ & 43.39 & 29.23 \\
\hline Equally-rich kin_out & $\begin{array}{c}2.273 \\
(4.473)\end{array}$ & $\begin{array}{c}1.635 \\
(1.983)\end{array}$ & 0.637 & $2.987 * * *$ & 36.66 & 34.34 \\
\hline Poorer kin_out & $\begin{array}{c}1.784 \\
(3.282)\end{array}$ & $\begin{array}{c}1.244 \\
(1.244)\end{array}$ & 0.540 & $3.218^{* * *}$ & 32.95 & 27.84 \\
\hline Share of richer kin_out & $\begin{array}{c}0.238 \\
(0.220)\end{array}$ & $\begin{array}{c}0.270 \\
(0.277)\end{array}$ & -0.032 & $-2.042^{* *}$ & 36.74 & 47.44 \\
\hline Share of poorer kin_out & $\begin{array}{c}0.130 \\
(0.171)\end{array}$ & $\begin{array}{c}0.155 \\
(0.206)\end{array}$ & -0.025 & $-2.065^{* *}$ & 31.63 & 37.67 \\
\hline
\end{tabular}

Note: In columns (1) and (2), Standard deviations in parentheses The "T-test" column displays results of an unpaired t-test. ${ }^{* * *}, * *$ and ${ }^{*}$ indicate respectively $1 \%, 5 \%$ and $10 \%$ respectively. In the last two colums, the condition MVV $>$ FVV holds if and only if the number of male relative (MVV) is larger than the number of female relatives (FVV). 
Table 7: Summary statistics on education and employment by gender.

\begin{tabular}{|c|c|c|c|c|c|}
\hline & $\mathrm{HH}$ & Male & Female & Diff & T-test \\
\hline Age & & $\begin{array}{c}44.057 \\
(13.970)\end{array}$ & $\begin{array}{c}37.928 \\
(11.722)\end{array}$ & $\begin{array}{l}6.129 \\
(7.522)\end{array}$ & $20.659^{* * *}$ \\
\hline No education (dv) & & $\begin{array}{l}.5209 \\
(.499)\end{array}$ & $\begin{array}{l}.6283 \\
(.483)\end{array}$ & $\begin{array}{l}-.1073 \\
(.600)\end{array}$ & $-4.530 * * *$ \\
\hline Primary Education (dv) & & $\begin{array}{l}.4416 \\
(.496)\end{array}$ & $\begin{array}{l}.3468 \\
(.476)\end{array}$ & $\begin{array}{l}0.0948 \\
(0.623)\end{array}$ & $3.861^{* * *}$ \\
\hline More than primary education $(\mathrm{dv})$ & & $\begin{array}{l}.0373 \\
(.189)\end{array}$ & $\begin{array}{l}.0248 \\
(.155)\end{array}$ & $\begin{array}{l}.0124 \\
(.200)\end{array}$ & $1.570^{* * *}$ \\
\hline Cash-potential worker (dv) & & $\begin{array}{c}0.4370 \\
(0.496)\end{array}$ & $\begin{array}{l}0.3639 \\
(0.481)\end{array}$ & $\begin{array}{l}.0730 \\
(.381)\end{array}$ & $4.855^{* * *}$ \\
\hline $\mathrm{HH}$ duration & $\begin{array}{c}18.227 \\
(12.430)\end{array}$ & & & & \\
\hline $\mathrm{HH}$ size & $\begin{array}{c}5.849 \\
(2.036)\end{array}$ & & & & \\
\hline HH monthly expenditures (BIF) & $\begin{array}{c}11188.43 \\
(25727.65)\end{array}$ & & & & \\
\hline Share of children under 15 & $\begin{array}{c}.515 \\
(.179)\end{array}$ & & & & \\
\hline Child median age & $\begin{array}{c}8.184 \\
(4.800)\end{array}$ & & & & \\
\hline
\end{tabular}

Note: "dv" and "BIF" stands for dummy variable and Burundian Francs, respectively. $\mathrm{N}=643$. Standard deviations in parentheses. The t-test is a paired t-test for all items. ${ }^{* * *}$ indicate significance at $1 \%$ level. 